\title{
Lygistorrhinidae (Diptera: Bibionomorpha: Sciaroidea) in early Eocene Cambay amber
}

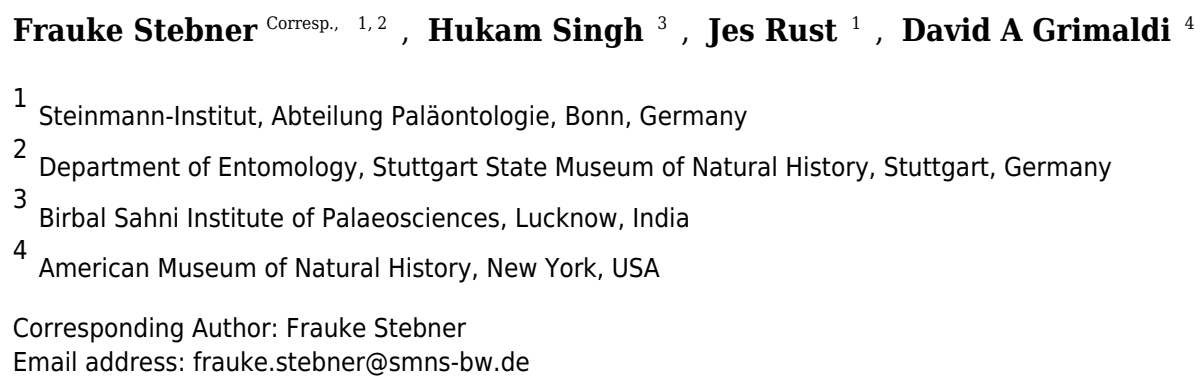

One new genus and three new species of Lygistorrhinidae in early Eocene Cambay amber from India are described, which significantly increases our knowledge about this group in the Eocene. Lygistorrhina indica n. sp. is the oldest fossil known from this extant genus. Indorrhina sahnii n. gen. et sp. shows morphological similarities to each of the two extant genera Lygistorrhina and Asiorrhina. Palaeognoriste orientale is the third species known from a group that has only been recorded from Eocene Baltic amber before. The latter finding reveals faunal links between Cambay amber and the probably slightly younger Baltic amber, adding further evidence that faunal exchange between Europe/Asia and India took place before the formation of Cambay amber. 
$2 \quad{ }^{1,2}$ Frauke Stebner, ${ }^{3}$ Hukam Singh, ${ }^{1}$ Jes Rust, ${ }^{4}$ David A. Grimaldi

3 'Steinmann-Institut, Abteilung Paläontologie, Bonn, Germany. Email: frauke.stebner@smns-

4 bw.de; jrust@uni-bonn.de.

$5 \quad{ }^{2}$ Stuttgart State Museum of Natural History, Stuttgart, Germany.

6 B3irbal Sahni Institute of Palaeosciences, Lucknow, India. Email: hukams@gmail.com.

$7 \quad{ }^{4}$ American Museum of Natural History, New York, USA. Email: grimaldi@amnh.org.

8 Corresponding author: Frauke Stebner. Email: frauke.stebner@smns-bw.de

\section{ABSTRACT}

One new genus and three new species of Lygistorrhinidae in early Eocene Cambay amber from India are described, which significantly increases our knowledge about this group in the Eocene. Lygistorrhina indica $\mathrm{n}$. sp. is the oldest fossil known for this extant genus. Indorrhina sahnii $\mathrm{n}$. gen. et sp. shows morphological similarities to each of the two extant genera Lygistorrhina and Asiorrhina. Palaeognoriste orientale is the third species known from a group that has only been recorded from Eocene Baltic amber. The latter finding reveals faunal links between Cambay amber and the probably slightly younger Baltic amber, adding further evidence that faunal exchange between Europe/Asia and India took place before the formation of Cambay amber.

\section{INTRODUCTION}

Lygistorrhinidae is a small dipteran group within the superfamily Sciaroidea (fungus gnats) of the infraorder Bibionomorpha. The monophyly of the latter two groups has been recently confirmed with high support by molecular analysis (Ševčík et al., 2016). Within the same analysis relationships of Lygistorrhinidae amongst other Sciaroidea indicates the inclusion of Lygistorrhinidae in the family Keroplatidae. Relationships within Lygistorrhinidae are well explored, with Parisognoriste and Palaeognoriste, both Eocene in age, being the sister groups to the remaining recent genera, consensus relationships of which are Asiorrhina (Lygistorrhina $($ Labellorhina + Blagorrhina + Gracillorhina $)+($ Matileola (Loyugesa + Seguyola $)))($ e.g., 
28

Members of Lygistorrhinidae can be found in tropical to temperate warm forests today (Grimaldi \& Blagoderov, 2001). They can be easily recognized by the distinct wing venation, with a lack of the stem and sometimes also the base of the fork of $\mathrm{M}$ veins, and generally an elongate proboscis, which is presumably for feeding from flowers (Seguyola lacks this as a derived condition) (Grimaldi \& Blagoderov, 2001). Apart from that however, ecology (e.g., life histories) and distributions of the species remains largely unknown. It has been concluded that rareness of this group in recent collections is due a lack of sampling, which is in turn related to poor knowledge about its biology and distribution (Grimaldi \& Blagoderov, 2001). Further, tropical regions like the Neotropics and Asia generally are still poorly collected and probably harbor a huge number of undiscovered species. This is supported by the increase of described genera (number more than tripled) and species (number more than doubled) in the past 15 years, particularly of recent genera from southern Asia (Grimaldi \& Blagoderov, 2001; Hippa, Mattsson \& Vilkamaa, 2005; Blagoderov, Hippa \& Ševčík, 2009) and from fossil taxa (Blagoderov \& Grimaldi, 2004; Blagoderov, Hippa \& Nel, 2010; Grund, 2012).

To date there are 15 genera, seven fossil and eight extant, and 48 species described (Pape, Blagoderov \& Mostovski, 2011; Fungus Gnats online, 2016). The fossil record of Lygistorrhinidae dates back to the Cretaceous, with the oldest records from Lebanon (125-129 Ma, Maksoud et al., 2016) (†Lebanognoriste Blagoderov \& Grimaldi, 2004), Myanmar (98-99 Ma, Shi et al., 2012) (†Archaeognoriste Blagoderov \& Grimaldi, 2004; $\uparrow$ Protognoriste Blagoderov \& Grimaldi, 2004; †Leptognoriste Blagoderov \& Grimaldi, 2004), Taimyr (Santonian, e.g., Rasnitsyn et al., 2016) (†Plesiognoriste Blagoderov \& Grimaldi, 2004) and Canada (76-80 Ma, e.g., Borkent, 2000) (†Plesiognoriste Blagoderov \& Grimaldi, 2004). There is then a large gap in the fossil record, with the next oldest members known from early Eocene Oise amber (ca. 53 Ma, Brasero, Nel \& Michez, 2009) (†Parisognoriste Blagoderov, Hippa \& Nel, 2010), amber from the Baltic Region (35-43 Ma, e.g., Standke, 2008) (†Palaeognoriste Meunier, 1904) and Dominican amber (15-20 Ma, Iturralde-Vinent, 2001) (Lygistorrhina Skuse, 1890; see Grund, 2012).

Findings of fossil Lygistorrhinidae in Eocene Cambay amber from India now fill a gap in the spatial fossil record of the Palaeogene. Cambay amber occurs in active lignite mines in the state of Gujarat, in western India. The amber-bearing sediments have been dated to 52-55 Ma (Clemetz et al., 2011; Garg et al., 2008; Punekar \& Saraswati, 2010; Sahni et al., 2006). More precisely, vertebrate remains from between the two major amber layers in Vastan mine have been estimated at 54.5 Ma (Smith et al., 2016), suggesting an age of ca 54 Ma for the amber. 
61 Thus Cambay amber is slightly older than Baltic amber and contemporaneous with Oise amber

62 from France and Fushun amber from China (50-53 Ma, Wang et al., 2014). Cambay amber has

63 been formed at a climatically pivotal period: namely during the Early Eocene Climatic Optimum

64 (EECO). Further, the time of formation of this amber (or at least its burial) is most likely around

65 the time of collision of the Indian subcontinent with Asia, which, according to most recent

66 stratigraphic results, took place around $59 \mathrm{Ma}$ (Hu et al., 2015) and led to the uplift of the

67 Himalaya. In previous studies, investigation of fossils from Cambay amber have proven to be of

68 major significance for the reconstruction of India's past diversity and geological history (e.g.,

69 Rust et al., 2010; Stebner et al., 2017).

70 Until now, eight fossil Lygistorrhinidae belonging to three species in three different genera have

71 been discovered in Cambay amber. These findings add further evidence that these flies are much

72 more abundant and diverse in past ecosystems than is commonly known, as it has also been

73 suggested for modern faunas. The fossils represent one species that is very similar to fossils of

74 the archaic Baltic amber genus Palaeognoriste, as well as two species that belong to more

75 derived, living lineages. Together with known fossil and recent species, and the highly congruent

76 phylogenetic analyses published so far, the finding of fossils in the early Eocene from India

77 provides interesting information for divergence-time estimations of this family, and eventually for

78 biogeographic studies.

79 Interestingly, to date no faunal connections between contemporaneous Cambay amber from India

80 and Oise amber from France have been found, though numerous affinities of fossils in Cambay

81 amber to Baltic amber have been recorded (Rust et al., 2010; Engel et al., 2011, 2013; Grimaldi

82 \& Singh, 2012; Stebner et al., 2017). Whether this is a consequence of the relatively nascent state

83 of investigation of the first two amber deposits, compared to the well-known Baltic amber, may

84 eventually be determined by additional future studies on Oise and Cambay amber. 
86 The present study is based on eight fossil Lygistorrhinidae in early Eocene Cambay amber from

87 India. The specimens derive from the Tadkeshwar lignite mine (N 21 $\left.{ }^{\circ} 21.400, \mathrm{E} 073^{\circ} 04.532\right)$ in

88 Gujarat, India. Screening of rough amber pieces was done at the Steinmann Institute, Bonn,

89 Germany and the American Museum of Natural History (AMNH), New York, USA. Holotypes

90 are deposited in the Birbal Sahni Institute of Palaeosciences (BSIP), Lucknow India; paratypes

91 retained in the $\mathrm{AMNH}$.

92 Amber pieces were ground using a Buehler Phoenix Beta grinding machine and Buehler wet-

93 lapidary wheel. For taxonomic identification and investigation a Leica MZ $12{ }_{5}$ stereoscope and

94 Nikon SMZ1500 were used. Photographs were taken with an AXIO Zoom.V16 stereomicroscope

95 (Carl Zeiss, Jena) equipped with an AXIOCam HRc digital camera (Zeiss), using the extended-

96 depth-of-focus function, and in New York with a Nikon SMZ1500 stereoscope, digital camera,

97 and Nikon NIS-Elements software.

98 Photo-plates were edited using Photoshop CS5.1 and Adobe Illustrator CS6.

99 General morphological terms and abbreviations follow those given in the Manual of Nearctic 100 Diptera (McAlpine, 1981) and in Blagoderov \& Grimaldi (2004). The spur formula refers to the 101 number of tibial spurs on fore-, mid-, and hind legs. Wing veins are abbreviated as follows: CuA 102 = anterior branch of cubital vein; $\mathrm{CuP}=$ posterior branch of cubital vein; $\mathrm{h}=$ humeral crossvein;

$103 \mathrm{M}_{1}-\mathrm{M}_{4}=$ branches of medial vein; $\mathrm{R}_{1}, \mathrm{R}_{5}=$ branches of radial vein; $\mathrm{r}-\mathrm{m}$ = radial-medial 104 crossvein; $\mathrm{Sc}=$ subcostal vein.

105 The morphological matrix is based on the matrix of Blagoderov et al., 2010. The data matrix was 106 created and edited in Mesquite ver. 2.6 (Maddison \& Maddison, 2009). Strict consensus 107 cladograms were obtained by using TNT (Goloboff et al., 2008) based on 60 adult morphological 108 characters (after Blagoderov et al., 2010) (matrix shown in Table S1). It was searched by the 109 "implicit enumeration" option with "auto-collapse searches" off. The consensus trees were 110 calculated by "strict (=Nelson)" using all trees and all taxa.

111 Nomenclatural Acts

112 The electronic edition of this article conforms to the requirements of the amended International 113 Code of Zoological Nomenclature, and hence the new names contained herein are available under 114 that Code from the electronic edition of this article. This published work and the nomenclatural 115 acts it contains have been registered in ZooBank, the online registration system for the ICZN. 116 The ZooBank LSIDs (Life Science Identifiers) can be resolved and the associated information 
117 viewed through any standard web browser by appending the LSID to the prefix

118 "http://zoobank.org/". The LSID for this publication is: urn:lsid:zoobank.org:pub:DD2F5D2A119 C3EE-4F5C-B068-C9E541D9B70C. 
Type species: Palaeognoriste sciariforme Meunier, 1904: 88, by monotypy. In Baltic amber. Matile 1990a: 360; Matile 1990b: 366, 373-376, 383, 409, 421, 554; Hoffeins and Hoffeins 1996: 311; Grimaldi and Blagoderov 2001: 55; Hippa, Mattsson \& Vilkamaa 2005: 5, 11; Blagoderov Hippa \& Ševčík 2009: 32, 33, 35, 37, 45; Blagoderov, Hippa \& Nel 2010: 79-81, 83-89. proboscis no longer than $2.5 \mathrm{X}$ head height, palpus one-segmented; wing with complete basal portion of fork of $\mathrm{M}_{1}-\mathrm{M}_{2}$, vein Rs and crossvein r-m present.

\section{Palaeognoriste orientale Stebner and Grimaldi, new species} LSID urn:lsid:zoobank.org:act:122BEB14-EDDA-45D7-9973-3898B609F39C

Diagnosis: Very similar to the two Palaeognoriste species in Baltic amber, except that $P$. orientale has a broader, shorter wing; the stem of $\mathrm{M}$ and base of $\mathrm{M}$ forks are absent (vs. faint); apex of vein $\mathrm{CuA}$ is more acutely bent; gonostylus is more curved; apex of the labellar lobes are blunt, not narrowly tapered; clypeus projecting forward, $\Omega$-shaped; antenna is much longer than proboscis (vs. approximately the same length).

Material: Holotype, male Tad-887, complete inclusion in early Eocene Cambay amber from India; deposited in the BSIP, Lucknow India. Paratypes, 1 male: Tad-587, 2 females: Tad-37A, Tad-324; deposited in the AMNH. India, $21^{\circ} 21.400^{\prime} \mathrm{N}, 73^{\circ} 4.532^{\prime} \mathrm{E}$.

Etymology: Specific name refers to the origin of the species from the Oriental Region. DESCRIPTION:

Measurements: Male. Head height: $0.24 \mathrm{~mm}$; body without head: $1.8 \mathrm{~mm}$; wing measured from humeral vein: $1.06 \mathrm{~mm}$; antenna: $0.8 \mathrm{~mm}$; proboscis: $0.23 \mathrm{~mm}$; palpus: $0.13 \mathrm{~mm}$.

Head (Fig. 1 E): Globular, occipital setae short, postocellar and frontal setae erect and stronger. extending to base of antenna. Facets round, equal in size (no differentiation), postocular setae present, interocular setae very fine, short, sparse. Number of ocelli three, forming triangle, middle ocellus slightly smaller than lateral ocelli. Palp one-segmented, evenly setose, ca. $0.55-0.6 \mathrm{X}$ 
151 length of proboscis. Proboscis short, about as long as head high, significantly shorter than

152 profemur; almost bare, with fine hairs on lower surface; apex blunt, not narrowly tapered.

153 Labrum narrowly triangular, without setae, length $0.25-0.30 \mathrm{X}$ that of proboscis. Antenna with 14

154 flagellomeres, none laterally flattened. Scape with a slim pedicel/stem and bulbous apical part;

155 pedicel bulbous, 1.8X wider than flagellomeres. Flagellomere 1 subcylindrical; flagellomeres 2-

15613 cylindrical, about $1.6 \mathrm{X}$ longer than broad. Terminal flagellomere elongate, evenly tapered to

157 rounded apex, about 1.5X length of proximal articles and 2.4X longer than broad.

158 Thorax: Scutum moderately convex, not dome-shaped or arched, evenly covered with short

159 setae, longer setae on posterolateral surfaces. Anterior margin of thorax slightly anterior to level

160 of procoxae. Laterotergite only slightly produced, not lobate, with row of 4-5 fine setae on

161 posterior margin. Scutellum with long, stiff setae on posterior margin.

162 Legs: Coxae nearly equal in length (fore coxa nearly equal in length to other two); fore coxa

163 sparsely setose anteriorly, mid coxa sparsely setose anteriorly on apical half, hind coxa bare

164 (holotype) or with very sparse, minute setae (paratype Tad-587). Hind coxa without concavity on

165 lateral surface. Tibiae and tarsi (Fig. 1 B, C) evenly covered with small setulae, arranged in

166 longitudinal rows. Mid tibia with six thick, erect, evenly-spaced setae. Tibial spurs 1:2:2, length

167 0.1: $(0.2,0.1):(0.46,0.26)$. Fore and hind tibiae slightly expanded towards apex. Short

168 transverse comb of thick setae on apex of hind tibia. All claws with pointed (none with blunt)

169 apex.

170 Wing (Fig. $1 \mathrm{~A}$, right wing): length of wing about 2.2X width, apex of wing not broadly rounded.

$171 R_{1}$ and $R_{5}$ with row of minute setae, other veins bare. Costa extending beyond $R_{5}$ tip to $2 / 3$

172 distance between tips of $\mathrm{R}_{5}$ and $\mathrm{M}_{1}$. Sc ending at $\mathrm{C}$. $\mathrm{R}_{1}$ ending slightly before middle of wing,

173 slightly curved posteriorly. Rs distinct, oblique. Crossvein $r-m$ present. $R_{5}$ slightly curved in basal

174 third. Stem of $M$ and base of $M_{1+2}$ fork lost. $M_{2}$ extends more basally than $M_{1} . M_{1}$ and $M_{2}$ straight

175 and parallel posteriorly, apices of $\mathrm{M}_{1}$ and $\mathrm{M}_{2}$ on each side of wing apex. $\mathrm{M}_{3+4}$ and $\mathrm{CuA}$ curved

176 posteriorly, $\mathrm{CuA}$ apex in paratype Tad-587 at nearly a right angle to $\mathrm{CuA}$ stem, more oblique in

177 holotype (possibly due to fold in the anal area). CuP very close and parallel to stem of $\mathrm{CuA}$.

178 Abdomen: Male terminalia (Fig. 1 D): Visible only from posterior in holotype; ventrally in 179 paratype Tad-587. Tergite 9 short and rounded apically, covered with short setae. Gonocoxites

180 wide in basal half, setose, mesal margin with dense small setae. Gonostylus cylindrical, slightly

181 curved; apex beveled, with two large setae - one on each apical edge (these not observed in

182 paratype Tad-587), a patch of thick, short setae between those, and with one subapical lobe-like

183 tooth. 


\section{Additional remarks:}

185 Tad-887 (Fig. 2 A-C): Holotype male; preservation: Complete, well displayed, with good 186 preservation, although there is a fracture running straight through the amber matrix. Eyes 187 contorted and sunken by fossilization. Right antenna with flagellomeres $6+7$ and 10+11 not 188 visibly/distinctly separated, probably due to fossilization processes. Anal lobe of right wing turned down, therefore margin not entirely visible.

Tad-587 (Fig. 3 A-E): Paratype male; preservation: Complete, well displayed, with good preservation, although the fly is encircled by a milky fracture. This, along with compression and some distortion of the thorax, obscures pleural structure. Details of the head, legs, and genitalia are very well preserved. The fly is viewed from its left side only, the right side obscured by an internal translucent fracture plane close to the fly. The area of the head vertex close to the antennae is obscured, so eye emarginations cannot be viewed. Measurements: Head height: not observable; proboscis length: $0.30 \mathrm{~mm}$; palpus length: 0.20 $\mathrm{mm}$; antenna length: $0.75 \mathrm{~mm}$; body length without head: $1.76 \mathrm{~mm}$; wing length from humeral vein: $1.10 \mathrm{~mm}$.

Tad-37A: Paratype female; preservation: Fair preservation, with legs and antennae well displayed but anterior portion of left wing lost at surface of the amber. Head is partially cleared (dorsum too poorly preserved to observe ocellar area); the fly straddles 3 fractures, which obscure some structures. The amber required trimming, embedding, and more trimming to obtain reasonable views.

204 Measurements: Head height: $0.23 \mathrm{~mm}$; proboscis length: $0.31 \mathrm{~mm}$; palpus length [not observable]; antenna length: $0.63 \mathrm{~mm}$; body length without head: ca. $1.6 \mathrm{~mm}$; wing length from humeral vein: $1.50 \mathrm{~mm}$.

Tad-324 (Fig. 4 A-B): Paratype female; preservation: Fair preservation, appendages (including mouthparts and antennae) well exposed, but some legs (especially prolegs) distorted by stretching. Wings intact but partly obscured by fracture over them; terminalia obscured. The amber required considerable trimming, then was embedded prior to more trimming. Measurements: Head height: $0.29 \mathrm{~mm}$; proboscis length: $0.37 \mathrm{~mm}$; palpus length $0.21 \mathrm{~mm}$; antenna length: $0.43 \mathrm{~mm}$; body length without head: $1.77 \mathrm{~mm}$; wing length from humeral vein:

\section{$1.37 \mathrm{~mm}$.}



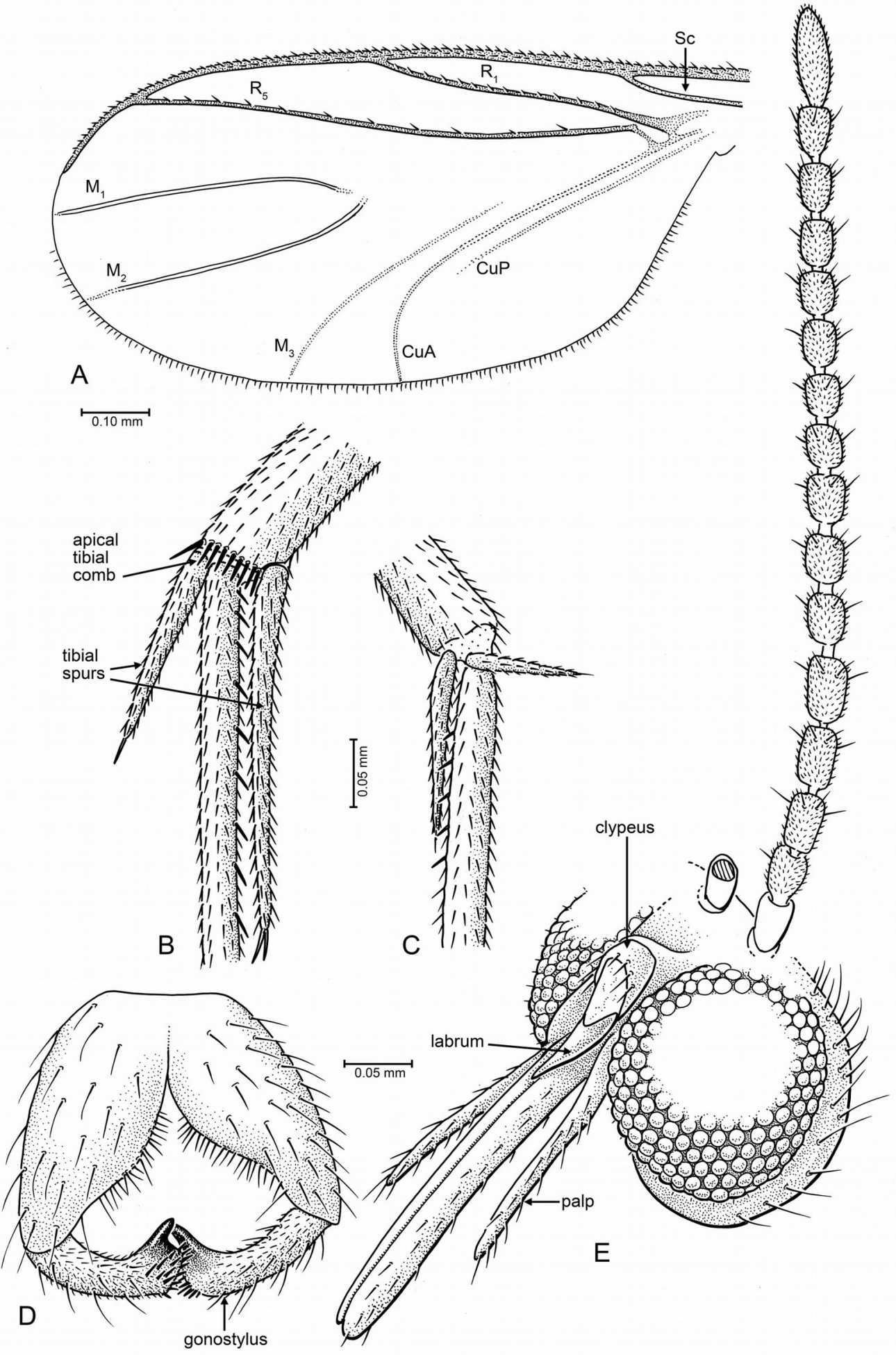

214 Fig. 1. Drawings of Palaeognoriste orientale n. sp., paratype male Tad-587. A. Wing. B, C. Tibial spurs (B, hind; C, mid). D. Male terminalia, ventral. E. Head, fronto-lateral. 

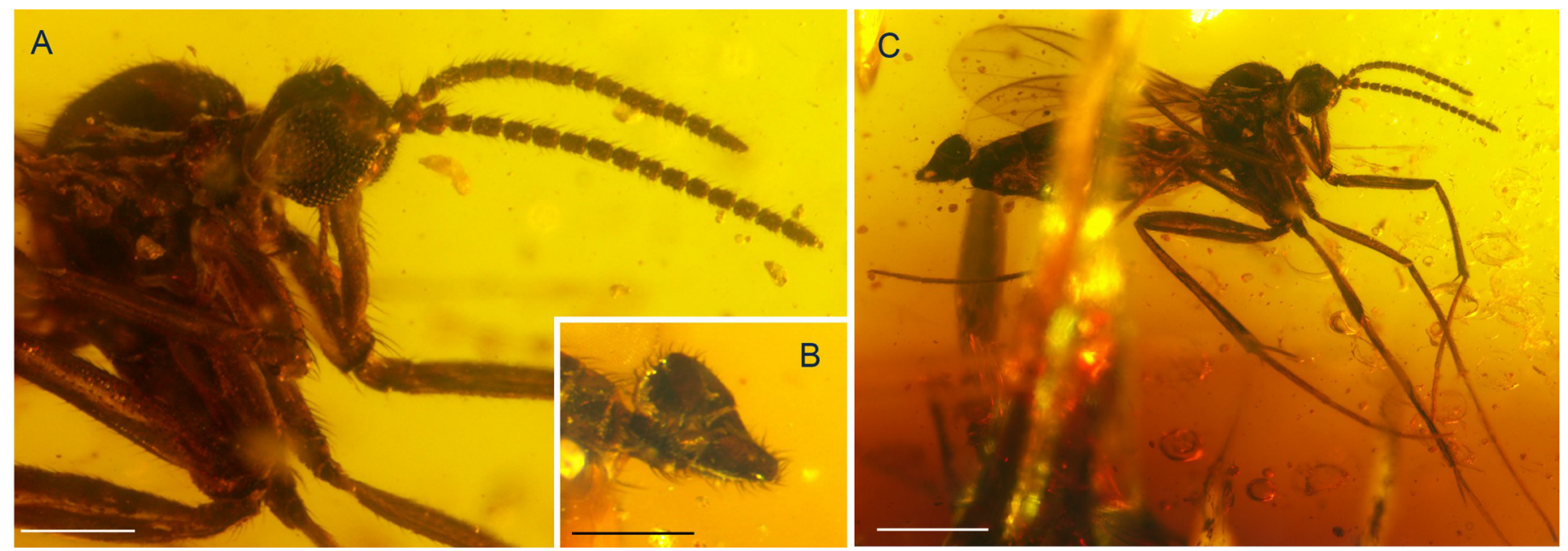

216 Fig. 2. Photographs of Palaeognoriste orientale n. sp., holotype male Tad-887. A. Thorax and 217 head, lateral. B. Male terminalia. C. Habitus, lateral view. Scale bars: A. $0.2 \mathrm{~mm}$, B. $0.2 \mathrm{~mm}$, C. $2180.5 \mathrm{~mm}$ 


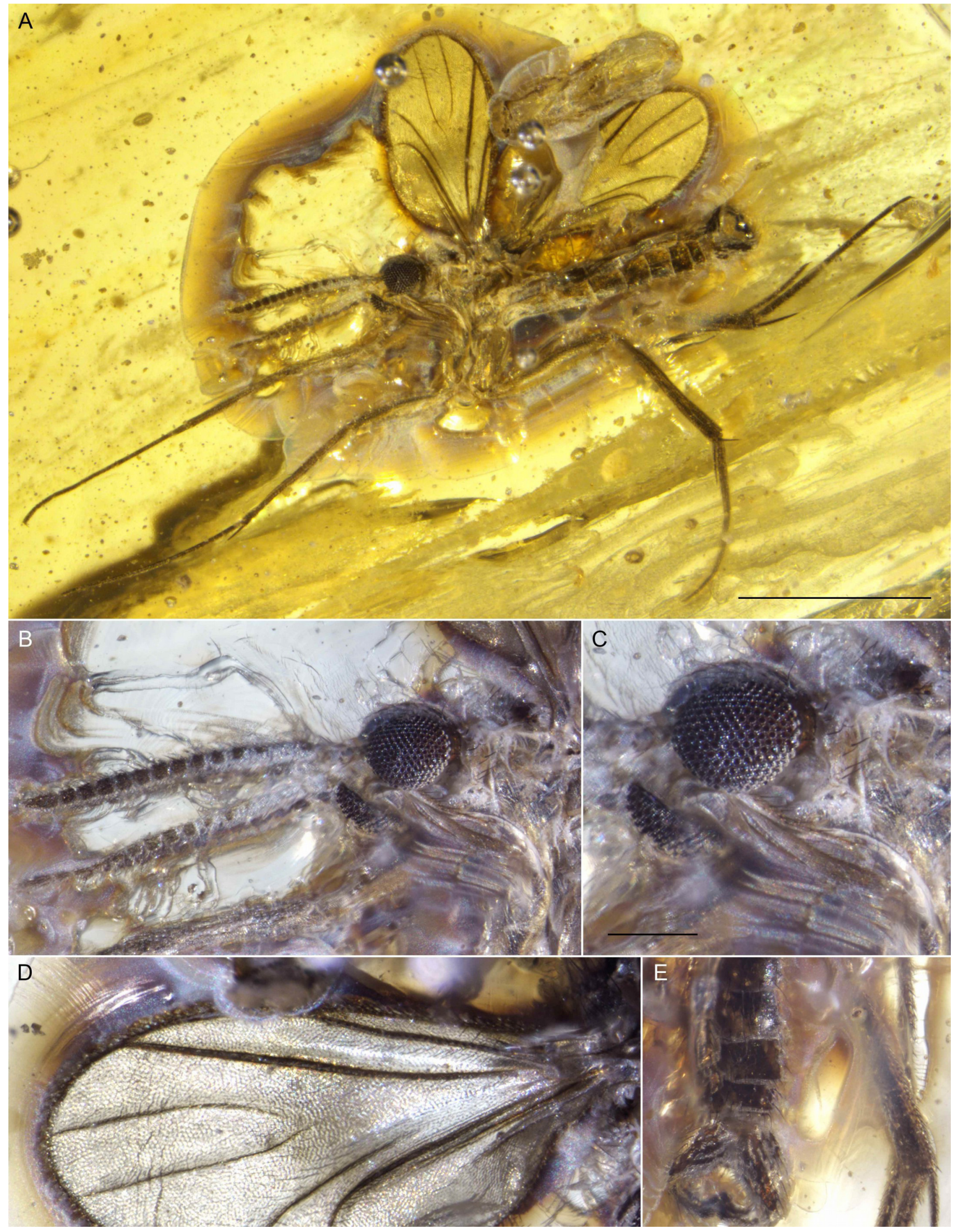


219 Fig. 3. Photographs of Palaeognoriste orientale n. sp., paratype male Tad-587. A. Habitus. B. 220 Head. C. Eyes. D. Wing. E. Male terminalia. Scale bars: A. 1 mm, C. 0.1 mm, D. 0.1 mm, E. 0.1 $221 \mathrm{~mm}$. 

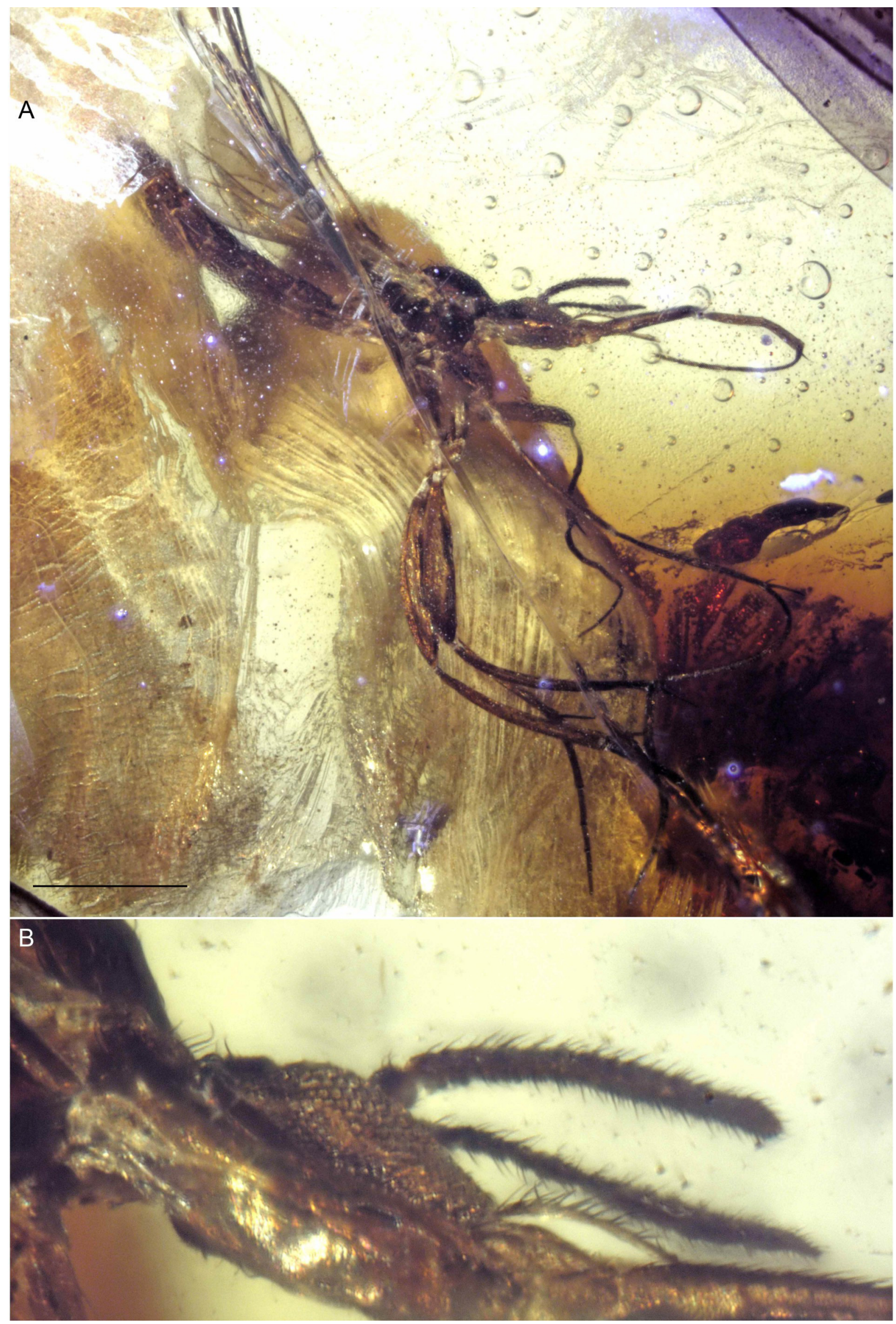
222 Fig. 4. Photographs of Palaeognoriste orientale n. sp., paratype female Tad-324. A. Habitus. B. 223 Head. Scale bars: A. $0.5 \mathrm{~mm}$, B. $0.1 \mathrm{~mm}$.

\section{Genus Lygistorrhina Skuse}

Type species: Type species: Lygistorrhina insignis Skuse, 1890: 600, by monotypy.

Williston 1896: 261; Johannsen 1909: 62; Edwards 1912: 203, 204; Senior-White 1922:197;

Edwards 1925: 530; Edwards 1926: 245, 246; Tonnoir 1929: 590; Edwards 1932: 139; Okada 1937: 46; Lane 1946: 345; Shaw \& Shaw 1951: 16; Hennig 1954:309; Lane 1958: 209, 210; Henning 1966: 50; Tuomikoski 1966: 254-260; Thompson 1975: 434-444; Matile 1979: 251-255; Matile 1986: 286-288; Matile 1990a: 359-362, 364-370; Matile 1996: 30; Huerta \& IbañezBernal 2008: 44-51; Evenhuis 2008: 13-19; Grimaldi \& Blagoderov 2001: 43-45, 47, 48, 52-54, 56; Papp 2002: 135,138-140; Papp 2005: 151-154; Hippa, Mattsson \& Vilkamaa 2005: 2 - 6, 8, 10, 11, 13, 16, 19; Blagoderov, Hippa \& Ševčík 2009: 31-33, 35, 37; Grund 2012: 639-642; Blagoderov, Papp \& Hippa 2013: 1, 2, 4-11.

Diagnosis after Grimaldi \& Blagoderov (2001): Head with proboscis $>4 \mathrm{X}$ length of head, including palps; wing with vein Sc incomplete or complete, basal portion of fork of $\mathrm{M}_{1}-\mathrm{M}_{2}$ lost, $\mathrm{CuA}_{1}$ and $\mathrm{CuA}_{2}$ not connected in distal fork. Thorax with laterotergite expanded outward, flaplike, with fringe of long setae on edge.

\section{Lygistorrhina indica Stebner and Grimaldi, new species} LSID urn:lsid:zoobank.org:act:C787AB55-78E4-4E19-940D-29BEAD5A2ABE

\section{Figs 5 B, 6 C, D, 7 B, 8 A-D, 9 A, B}

Diagnosis: Very similar to recent and Neogene species of Lygistorrhina by the very long, slender proboscis and palpi; anterior ocellus small to minute; laterotergite lobate and setose; stem of $\mathrm{M}$ and bases of $M_{1}-M_{2}$ fork absent; $R_{5}$ without setae. Differing from other species of the genus by lack of concavity on lateral surface of metacoxa, and setae on laterotergite not in a row on posterior margin.

Material: Holotype, female Tad-442, complete inclusion in early Eocene Cambay amber from India; deposited in the BSIP. Paratypes, 1 female: Tad-492, 1 incomplete specimen of unknown sex: Tad-888, deposited in the AMNH.

Locality: Cambay Formation (early Eocene), Tadkeshwar lignite mine, Tadkeshwar, Gujarat, India, $21^{\circ} 21.400^{\prime} \mathrm{N}, 73^{\circ} 4.532^{\prime} \mathrm{E}$. 
252 Etymology: Specific name refers to the origin of the amber from India.

\section{DESCRIPTION:}

254 Measurements: Measurements: Head height: $0.29 \mathrm{~mm}$; proboscis length: $0.90 \mathrm{~mm}$; palpus

255 length: $0.61 \mathrm{~mm}$; antenna length: $0.58 \mathrm{~mm}$; body length without head: $2.17 \mathrm{~mm}$; wing length

256 from humeral vein: $1.32 \mathrm{~mm}$. Only female known.

257 Head (Fig. 5 B): Subspherical, occiput and vertex short setose. Eyes with facets round and equal

258 in size, ommatidia very densely set. Postocular setae not present or not visible, interocular setae

259 short, sparse, very fine. Eyes emarginate just lateral to antennal base; emarginate area bare of ca.

260 one row of facets. Number of ocelli three, nearly in a transverse line, middle ocellus significantly

261 smaller than lateral ocelli. Frons and face broad; extensive membranous area ventral and lateral to

262 antennal bases, with small sclerotized condyle. Clypeus slightly crescentic, with marginal setae.

263 Palpi one-segmented, long, 0.7X the length of proboscis, tapered apicad to fine tip, with a single

264 row of setae. Proboscis evenly curved (of medium length), (very long in Tad-442, Tad-492) about

$2652.2 \mathrm{X}(3.3 \mathrm{X})$ as long as head high, with fine short setae. Oral margin slightly protruding; deeply

266 incised, with clypeus nestled fully within. Labrum long triangular, with rounded apex, without

267 setae. Antenna with 14 flagellomeres. Scape bulbous; pedicel subcylindrical, broadened apically,

268 1.8X wider than flagellomeres. Flagellomeres 1-13 cylindrical, about 1.2X longer than broad.

269 Terminal flagellomere evenly tapering to rounded apex, only slightly longer than previous ones

270 and $1.5 \mathrm{X}$ longer than broad.

271 Thorax (Fig. 6 D): Scutum dome-shaped, strongly arched, entirely covered with setae of medium

272 length; acrostichals long, longer setae on posterolateral surface of scutum. Scutellum with a row

273 of long setae on posterior margin. Thorax in lateral view short (anterior to posterior margins),

274 tall/deep (dorsal to ventral margins). Laterotergite well produced posteriad into a lobe, with long

275 setae over broad surface (not in marginal row).

276 Legs: Coxae virtually equal in length. Fore coxae setose anteriorly, mid and hind coxae with

277 sparse setae laterally. Fore tibia evenly covered with short setae, with one tibial spur, not

278 expanded towards apex, approximately equal in length to fore femur. Tibiae and tarsi with

279 microtrichia in longitudinal rows. Tibial spurs $1: 2: 2$; anterior midtibial spur $0.3 \mathrm{X}$ length of

280 other spur. Hind tibia with apico-lateral comb of thick, short setae (presence/absence of

281 depression here not observable). Hind coxa without lateral concavity. Tips of all claws pointed,

282 none blunt.

283 Wing (Fig. 7 B): Fairly short and broad, length/width 2.13, apex rounded but not extensively so.

$284 R_{1}$ setose, $R_{5}$ without setae, other veins bare. Costa extending to approximately $2 / 3$ distance 
285 between $\mathrm{R}_{5}$ and $\mathrm{M}_{1}$. Sc ending at $\mathrm{C}$. $\mathrm{R}_{1}$ slightly curved posteriorly, apex ending beyond middle of 286 wing. $R_{5}$ moderately sinuous in apical third. $M$ stem and bases of $M_{1+2}$ fork lost. $M_{2}$ extends 287 slightly more basally than $\mathrm{M}_{1}$. CuP very close and parallel to stem of $\mathrm{CuA}$; apex of $\mathrm{CuA}$ strongly 288 curved, almost perpendicular to stem of $\mathrm{CuA}$. Anal lobe well developed.

289 Abdomen: That of female long, slender, tubular, cerci two-segmented (Fig. 6 C); male unknown. 290 Additional remarks:

291 Tad-442 (Fig. 5 B, 6 C, 7 B, 8 A, B): Holotype female; preservation: The specimen is very well 292 preserved and virtually complete save for the distal tarsomeres of 4 legs (which are lost at the 293 amber surface). Head and its appendages are very well preserved and fully observable; right 294 wing is slightly distorted by preservation, but the left wing is well preserved. A fully lateral view 295 (e.g., thorax) is not observable.

296 Tad-492 (Fig. 6 D, 8 C, D): Paratype female; preservation: Specimen is largely complete but not intact; dorsum of the thorax and abdomen are separated from the rest of the body along with the wings (which are still attached to the thorax); a fracture along the line of separation prevents a

299 full lateral view of the intact portion of the pleurites. Otherwise, the head and its appendages, 300 legs, wings, and terminalia are well preserved with many details observable.

301 Measurements: Head height: $0.38 \mathrm{~mm}$; proboscis length: $0.90 \mathrm{~mm}$; palpus length: $0.45 \mathrm{~mm}$; 302 antenna length: $0.68 \mathrm{~mm}$; body length without head: $2.64 \mathrm{~mm}$; wing length from humeral vein: $3031.83 \mathrm{~mm}$.

304 Tad-888 (Fig. 9 A, B): Paratype, sex unknown; preservation: Most of abdomen and mid and hind 305 legs missing; both wings incomplete.

306 Measurements: Head height: $0.22 \mathrm{~mm}$; antenna: $0.5 \mathrm{~mm}$; proboscis: $0.5 \mathrm{~mm}$; palpus: $0.35 \mathrm{~mm}$. 


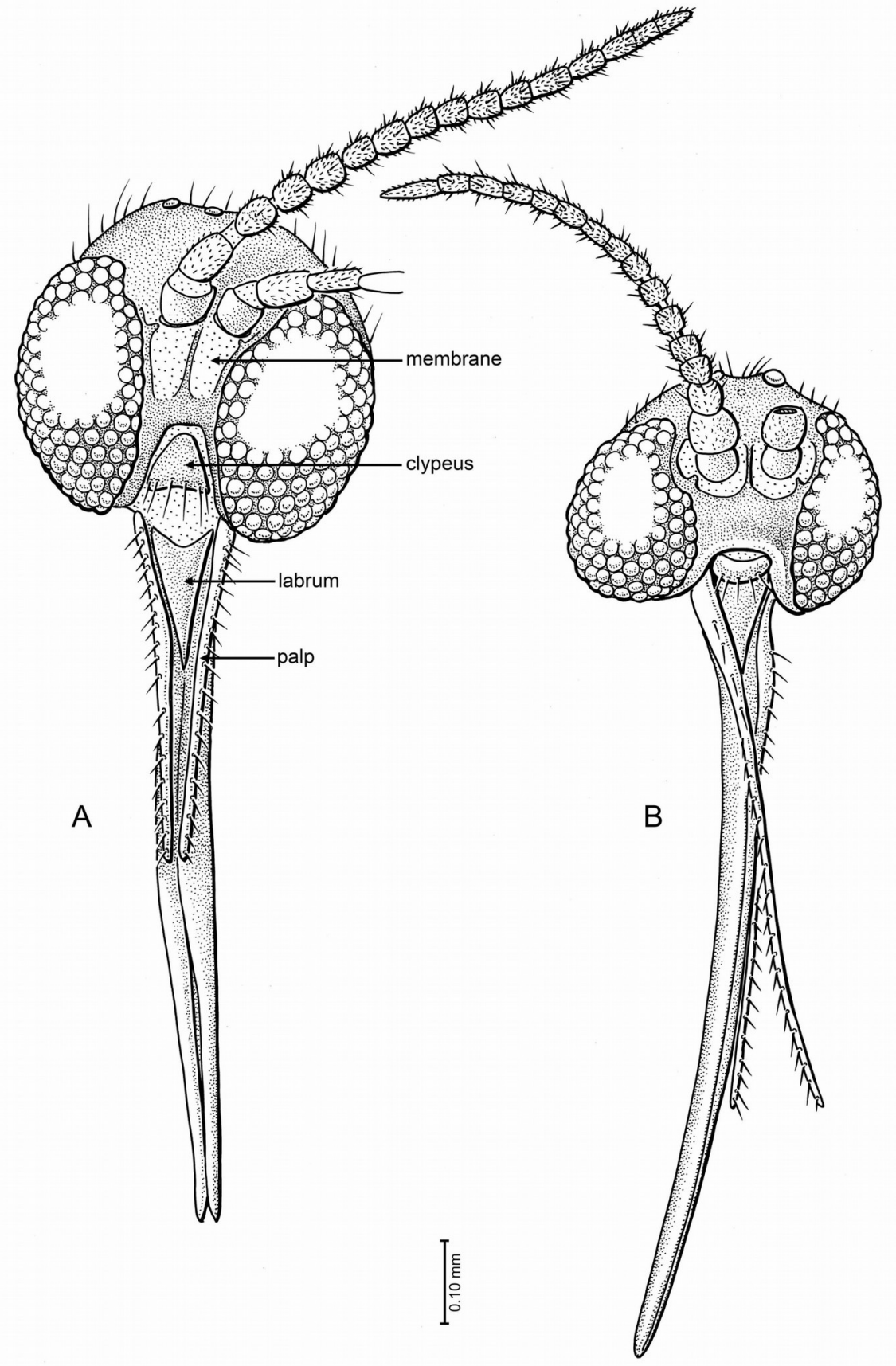

307 Fig. 5. Drawings of frontal view of heads (same scale). A. Indorrhina sahnii n. sp., holotype Tad308418 B. Lygistorrhina indica n. sp., holotype Tad-442. 


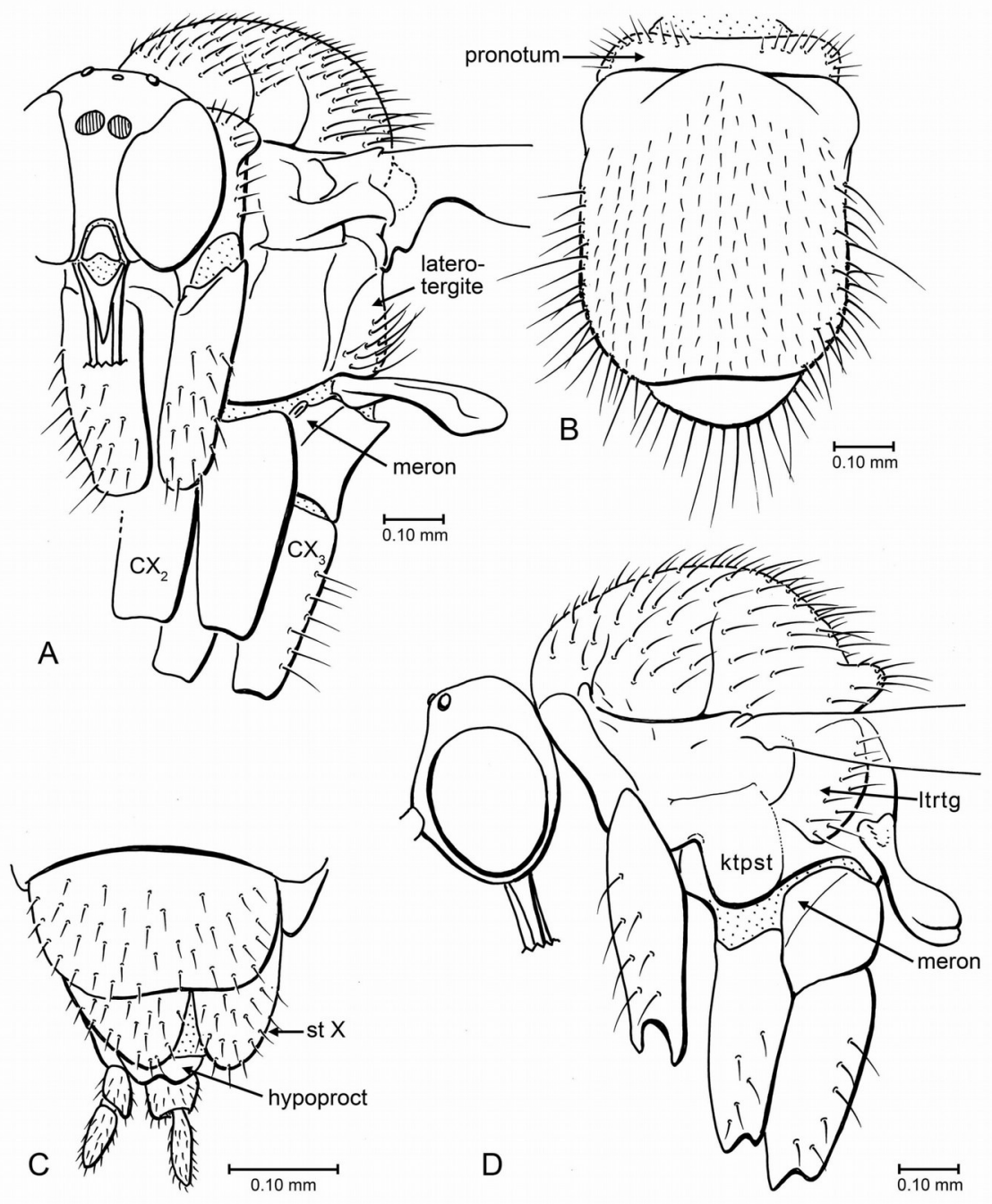

309 Fig. 6. Drawings of head, thorax and terminalia. A. Indorrhina sahnii n. sp., holotype Tad-418, 310 head and thorax, fronto-lateral view. B. Indorrhina sahnii n. sp., holotype Tad-418, thorax, 311 dorsal. C. Lygistorrhina indica n. sp., holotype Tad-442, female terminalia, ventral. D. 312 Lygistorrhina indica $\mathrm{n}$. sp., paratype Tad-492, thorax and head, lateral (thorax reconstructed from 313 both sides). Only the base of the proboscis is shown in figs. A, D. 


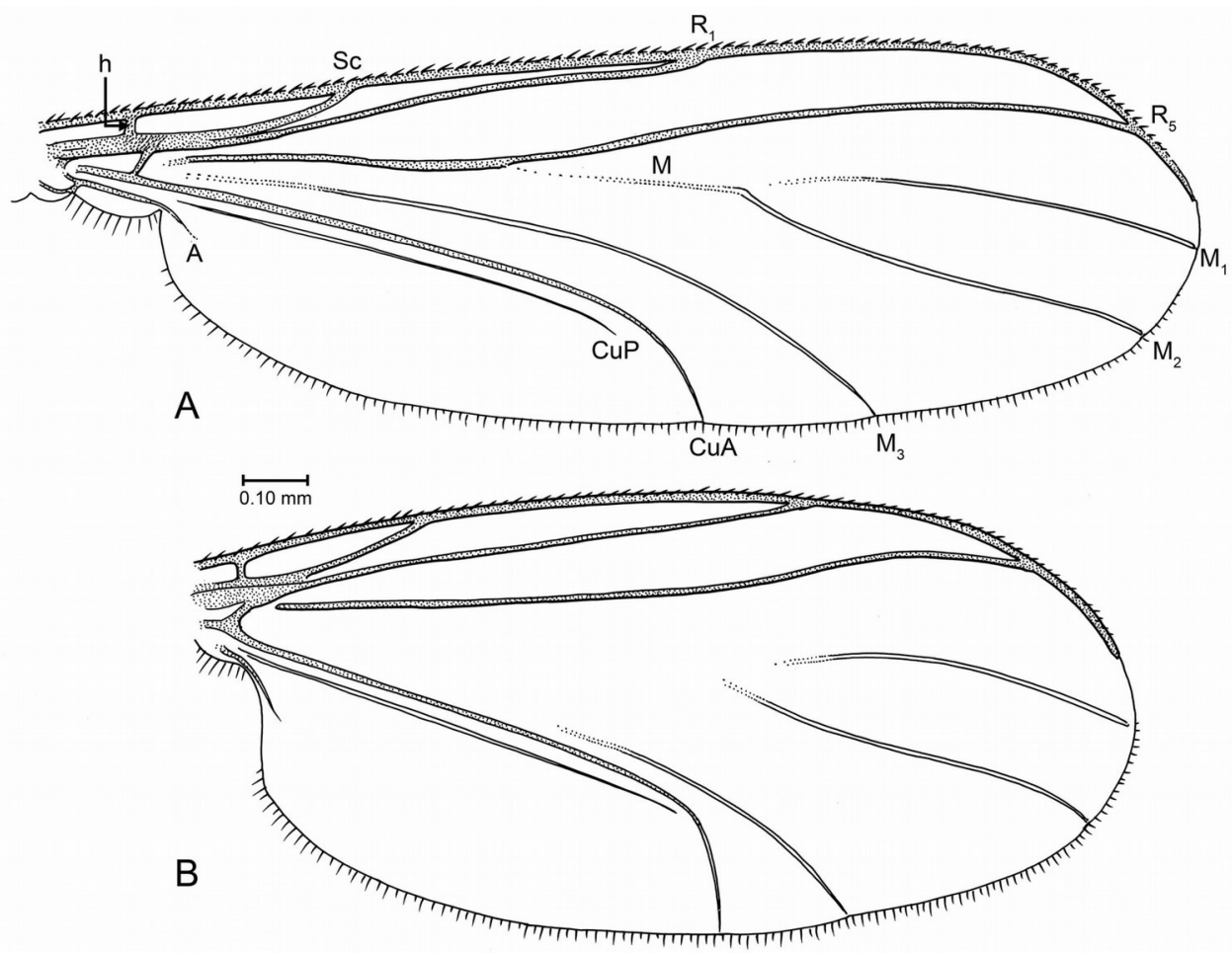

314 Fig. 7. Drawings of wings (same scale). A Indorrhina sahnii n. sp., holotype Tad-418. B. 315 Lygistorrhina indica n. sp., paratype Tad-492. 


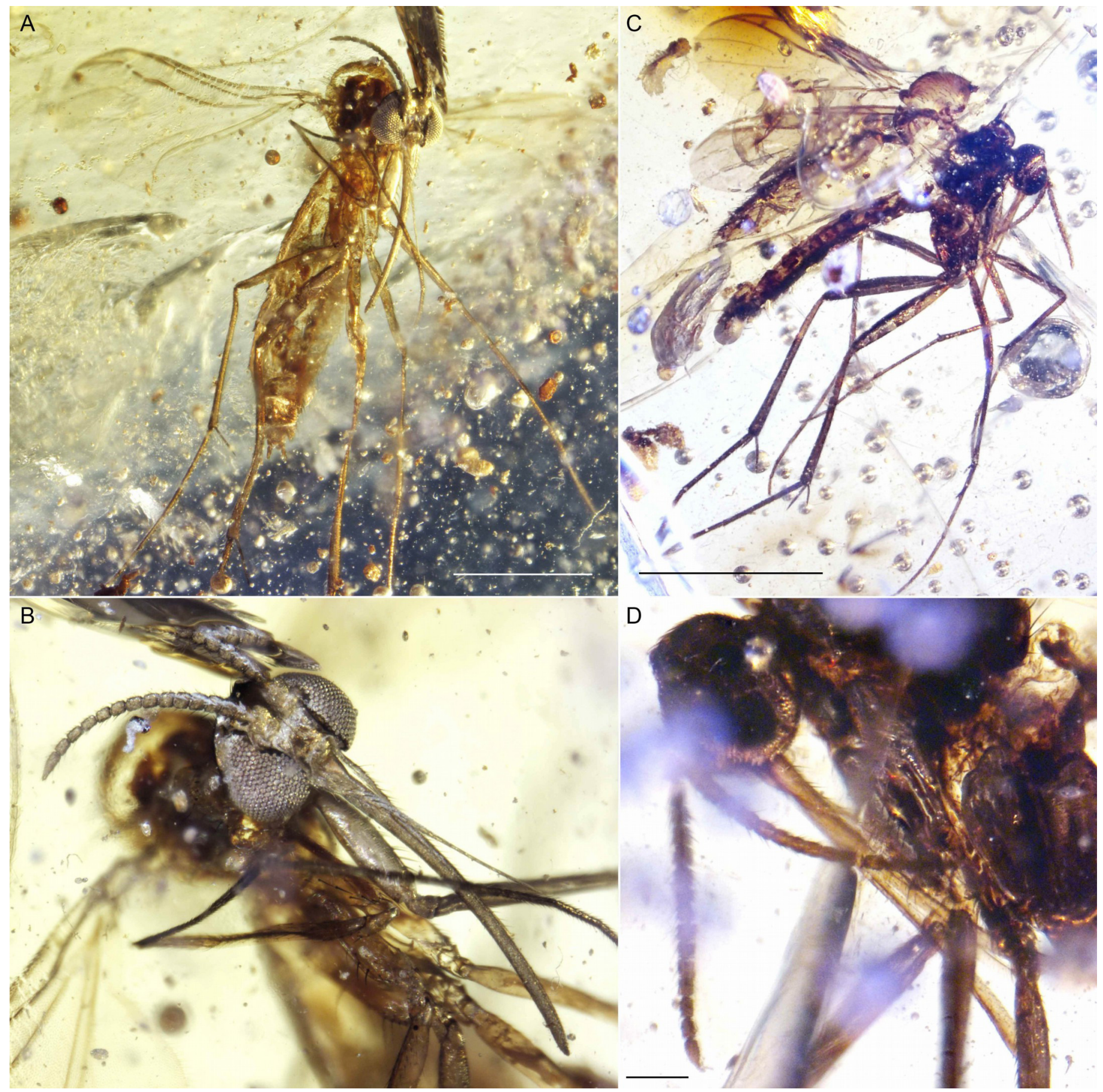

316 Fig. 8. Photographs of Lygistorrhina indica n. sp. A. Lygistorrhina indica n. sp., holotype female

317 Tad-442, habitus, fronto-lateral view. B. Lygistorrhina indica n. sp., holotype female Tad-442,

318 head, frontal view. C. Lygistorrhina indica n. sp., paratype Tad-492, habitus, lateral view. D.

319 Lygistorrhina indica n. sp., paratype Tad-492, head, lateral view. Scale bars: A. 0.5 mm, C. 1 mm, D. $0.1 \mathrm{~mm}$. 

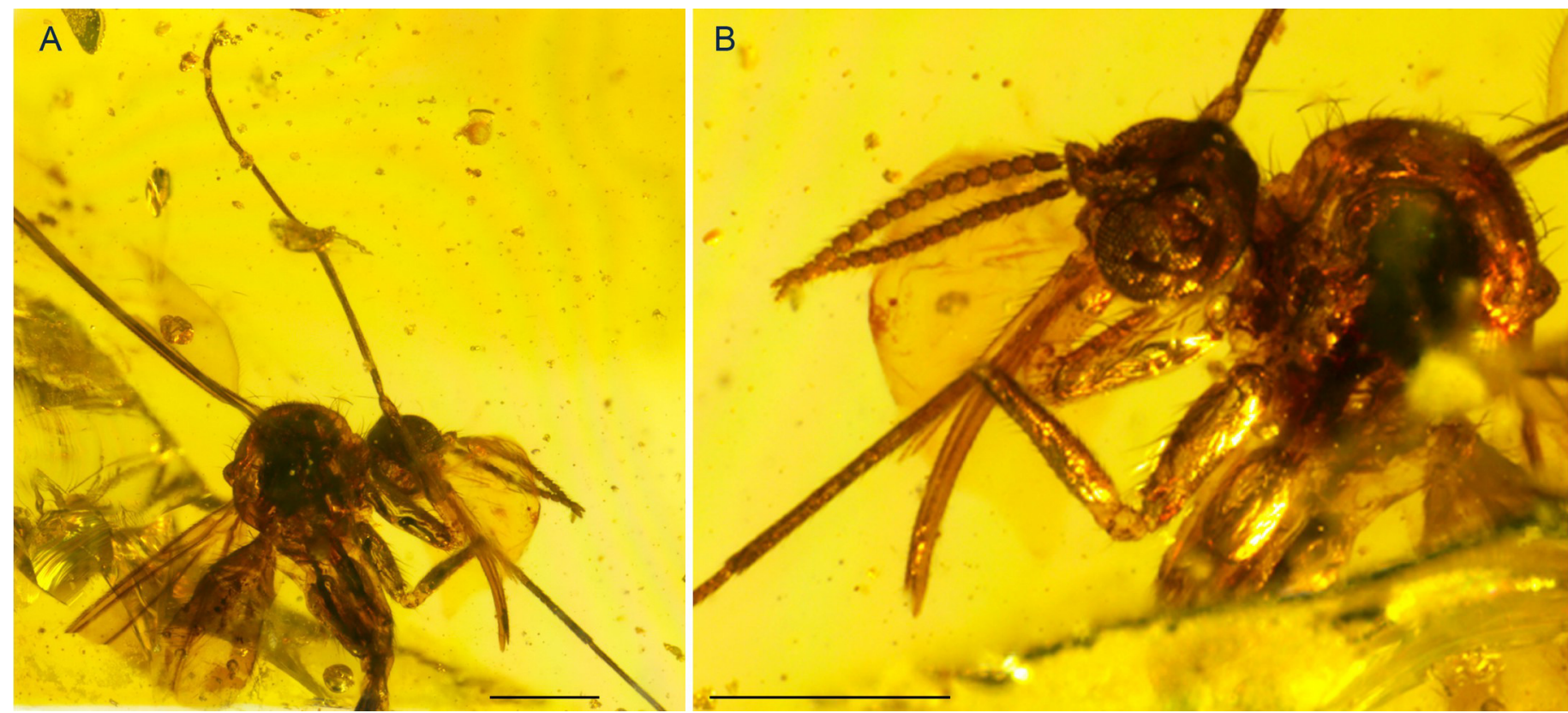

321

322

323

\section{Indorrhina Stebner and Grimaldi, new genus}

LSID urn:1sid:zoobank.org:act:D8BCCDD4-D601-467A-9478-482E3ADF269C

\section{Figs 5 A, 6 A, B, 7 A, 10 A-D}

Diagnosis: Proboscis moderately long (ca. 2.17X head length); antenna with 14 flagellomeres, articles cylindrical in shape; antenna relatively short (1.8X length of head); median ocellus small, in nearly transverse line with lateral ones; laterotergite lobate, setose; wing relatively long and narrow, length/width 2.8; Sc complete; stem of $\mathrm{M}$ and bases of $\mathrm{M}_{2}$ branch present but faint to spectral; hind coxa without lateral concavity.

Type Species: Indorrhina sahnii, n.sp.

Comments: The new genus appears to be phylogenetically intermediate between Asiorrhina and Lygistorrhina. The proboscis length is shorter than in Lygistorrhina, more similar to that of Asiorrhina (2.05-1.75X head depth). Unlike Asiorrhina, however, the antenna of Indorrhina is not laterally flattened and is considerably shorter (1.8X head depth, vs. 2.5X in Asiorrhina). Since the male of Indorrhina is unknown, it cannot be checked if the gonostylus is apically forked, a unique characteristic of Asiorrhina. Conditions of the ocelli and laterotergite in Indorrhina are shared with Lygistorrhina. Indorrhina differs from that genus by a hind tibia that 
340 is not apically broadened, lack of a concavity on the hind coxa, the shorter proboscis, and by

341 retaining bases to $\mathrm{M}$ veins, a feature that also separates it from the two other Eocene taxa

342 Palaeognoriste and Parisognoriste.

343 Etymology: Prefix based on India; suffix, -rrhina, from the Greek for nose or proboscis, in 344 reference to the slender proboscis.

Indorrhina sahnii Stebner and Grimaldi, new species

348 Diagnosis: As for the genus, by monotypy.

349 Material: Holotype, female, Tad-418, in Early Eocene Cambay amber, deposited in the BSIP.

350 Locality: Cambay Formation (early Eocene), Tadkeshwar lignite mine, Tadkeshwar, Gujarat, 351 India, $21^{\circ} 21.400^{\prime} \mathrm{N}, 73^{\circ} 4.532^{\prime} \mathrm{E}$.

352 Etymology: Patronym for Professor Ashok Sahni, dean of Indian paleontology, who provided 353 advice and encouragement to the authors for research on Cambay amber.

354 DESCRIPTION: Based on unique female, Tad-418 (holotype).

355 Measurements: Head height: $0.39 \mathrm{~mm}$; body without head: $2.68 \mathrm{~mm}$; wing length, from humeral 356 vein: $1.94 \mathrm{~mm}$; antenna length: $0.76 \mathrm{~mm}$; proboscis length: $0.81 \mathrm{~mm}$; palpus length: $0.43 \mathrm{~mm}$.

357 Head (Fig 5 A): Slightly flattened antero-posteriad (not subspherical), occipital and postocellar 358 setae well developed, frontal setae absent. Eyes well separated (frons well developed), with 359 slight medial emargination near antennal base; no differentiation of facets; interocular setulae 360 very short, sparse, and fine. All three ocelli present, median ocellus smaller than lateral ones, in nearly transverse line. Face well developed, with a large membranous area beneath each antennal base. Oral margin very deeply incised, with clypeus (roughly trapezoidal in shape) closely fitting into oral margin; clypeus flat, surrounded by membrane, anterior margin with row of 6 setae. Palp moderately long, length $0.5 \mathrm{X}$ that of proboscis; 1-segmented, with longitudinal row of $>20$ setae along all of lateral surface; palp slightly tapered apicad. Labrum long triangular, anterior margin concave, glabrous. Proboscis moderately long, length $2.17 \mathrm{X}$ the head depth, relatively stout (particularly at base), longer than fore femur. Antenna with 14 flagellomeres, total length relatively short (1.8X depth of head). Scape bare, barrel-shaped; pedicel longer than wide; flagellomeres longer than wide, lengths greater in apical four articles, cylindrical (not laterally flattened); each flagellomere with subapical whorl of setae; apical flagellomere tapered. 
371 Thorax (Figs 6 A, B): Scutum convex but not strongly arched or dome-shaped; entirely covered

372 with setae. Acrostichals long, arranged into fairly even rows; long setae on lateral margins of

373 scutum. Scutellum short and broad, with row of 12-14 long setae on posterior margin, no setae on

374 dorsal surface. Pleura mostly bare. Laterotergite lobate, with posterior and ventral margins raised

375 above pleural wall; setose, setae not confined to posterior margin.

376 Legs: Fore coxa slightly longer than other coxae; fore coxa and hind coxa setose; mid coxa bare;

377 hind coxa without lateral concavity. Tibiae and tarsi with longitudinal rows of setulae. Fore tibia

378 slightly longer than fore femur. Tibial spurs $1: 2: 2$. Hind tibia with short, transverse comb of

379 thick setae at apex. All pretarsal claws with apices pointed, none blunt.

380 Wing (Fig. 7 A): Wing relatively long and narrow, length/width 2.8, apex of wing not broadly

381 rounded. Vein $\mathrm{C}$ extended to approximately $2 / 3$ distance between $\mathrm{R}_{5}$ and $\mathrm{M}_{1}$. Sc complete; $\mathrm{R}_{1}$

382 ending slightly beyond mid-length of wing. Presence/absence of setulae on R veins not

383 observable. Stem of $M$ and base of $M_{2}$ fork present but faint to spectral, base of $M_{1}$ lost; $M_{1}$ and

$384 \mathrm{M}_{2}$ parallel for most their length; $\mathrm{M}_{1}$ ending at wing apex. $\mathrm{M}_{3+4}$ largely intact, most of stem

385 present (though incomplete); $\mathrm{CuA}$ long, apically curved but not acutely so; CuP close and parallel

386 to $\mathrm{CuA}$. Anal lobe present but not highly developed.

387 Abdomen: Long, slender, tubular; cerci 2-segmented.

388 Remarks:

389 Holotype Tad-418; preservation: Specimen is complete and fully intact, though portions are

390 obscured: the ventral abdominal region by a bubble, and portions of the mid- and hind tibiae and

391 tarsi from a fracture through the piece. The head, proboscis, thorax, and wings are particularly

392 well preserved, with no collapse or crumpling of the cuticle. A full frontal view of the head is

393 observable, but only an oblique view of the thoracic plura is possible. 


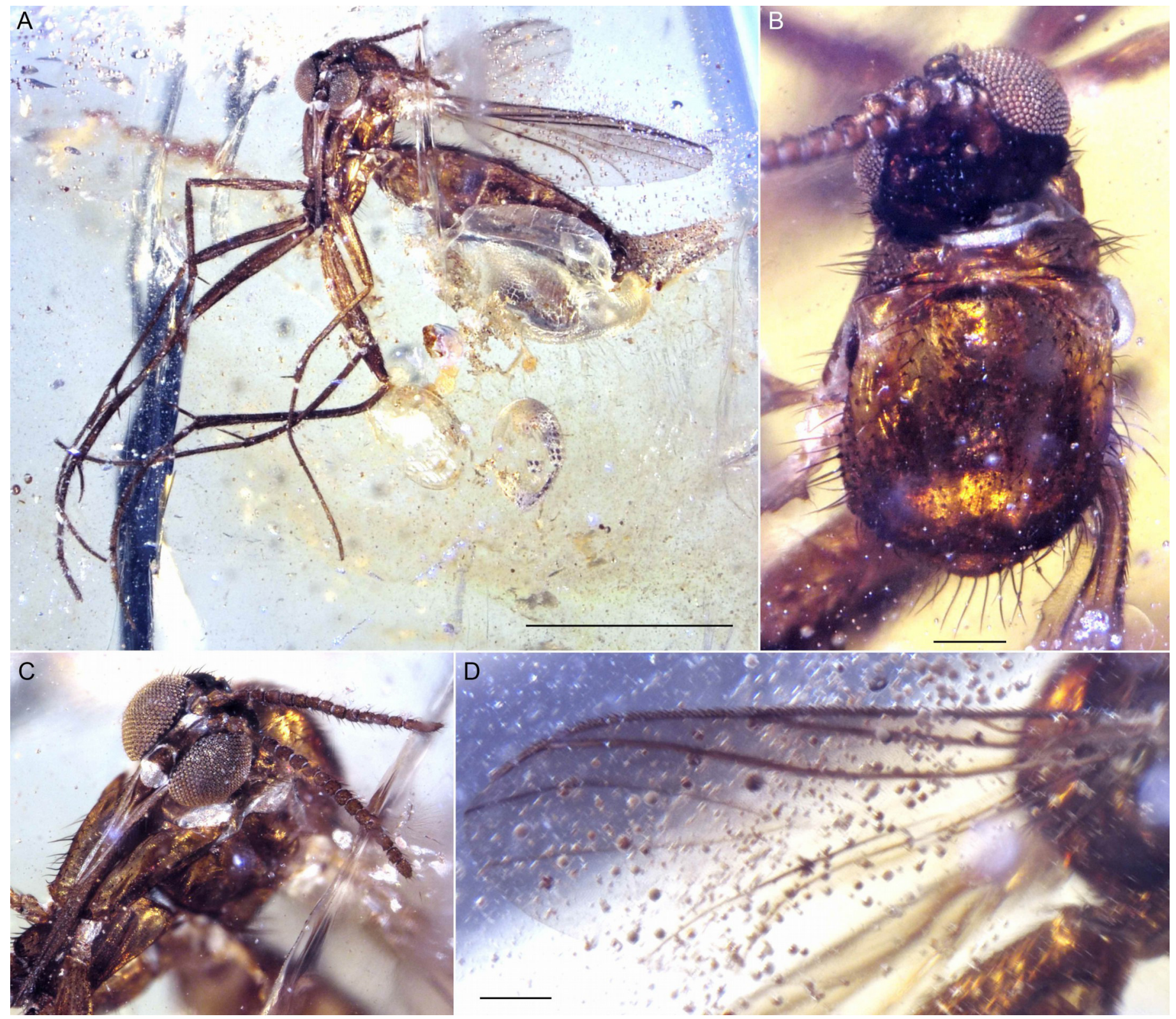

394 Fig. 10. Photographs of Indorrhina sahnii n. gen et sp., holotype female Tad-418. A. habitus, 395 lateral view. B. Thorax and head, dorsal view. C. Head, frontal view. D. Wing. Scale bars: A. 1 $\mathrm{mm}$, B. $0.1 \mathrm{~mm}$, D. $0.1 \mathrm{~mm}$. 


\section{DISCUSSION}

398 With eight fossils in three species and three different genera the diversity of Lygistorrhinidae in 399 Cambay amber exceeds that in Baltic amber, which has revealed only two species within the 400 genus Palaeognoriste so far (P. affine Meunier, 1912 and P. sciariforme Meunier, 1904). This is 401 most surprising considering the profound differences in sampling. Baltic amber is the best studied amber deposit in the world. Being mined commercially for decades, probably tens-of-thousands of insect inclusions are sorted out every year. In contrast, Cambay amber, which has been collected and studied only a few years, has revealed about 2000-3000 insect inclusions so far, overall based on work in four labs (BSIP, AMNH, Steinmann Institute Bonn, University of Kansas). A reasonable explanation for the greater diversity of Lygistorrhinidae in Cambay amber may be found in the climatic conditions prevailing at the time of amber formation. Recent Lygistorrhinidae are essentially circumtropical, occurring around the world in tropical regions (even remote islands), their northernmost extensions being into wet, warm temperate areas of southeast U.S. (Lygistorrhina sanctacatherinae) and Japan (L. pictipennis). At the time of amber formation the Indian subcontinent was just entering the equatorial humid-belt (e.g. Kent and Muttoni, 2008), resulting in an extremely hot and humid tropical climate. Virtually all plants recorded from Vastan mine are restricted to tropical and subtropical regions today, i.e. they grow under very warm and very humid conditions. It has therefore been concluded that the palaeoflora is indicative of a warm and very humid climate, with certain elements such as dipterocarps suggesting a tropical rainforest growing in the vicinity of Vastan (Singh et al., 2015; Tripathi \& Srivastava, 2012). More precisely, the reconstruction depicts a terrestrial lowland environment with a mesophytic mixed forest growing under tropical climate and with sufficient humidity (Singh et al., 2015). This general reconstruction of the Eocene palaeoforest in India fits well with the ecological requirements of extant representatives of Lygistorrhinidae.

The fossil record of Lygistorrhinidae shows a high congruence with the cladistic results, i.e. earlier fossils represent only older lineages (see phylogenetic analysis in Blagoderov \& Grimaldi, 2004; Blagoderov, Hippa \& Nel, 2010). The genera only known from Cretaceous ambers seem to belong to a basal stem group, whereas Palaeognoriste, which is only known from the Eocene, presumably represents a sister group to all the extant genera (Blagoderov \& Grimaldi, 2004; Blagoderov, Hippa \& Nel, 2010). The taxa found in Cambay amber clearly support this by the absence of 'Cretaceous' taxa and by the presence of the 'Eocene' taxon Palaeognoriste, as well as the presence of the phylogenetically younger extant genus Lygistorrhina, and the fossil genus 
429 Indorrhina n. gen., which appears to be within the clade of extant taxa that form the sister group 430 to Palaeognoriste (Figure 11).

431 Paleognoriste orientale n. sp. possesses at least 7 features that differ with the two species of the 432 genus in Baltic amber: broader, shorter wing; stem of $M$ and base of $M$ forks absent; apex of 433 vein $\mathrm{CuA}$ more acutely bent; gonostylus more curved; apex of labellar lobes blunt; clypeus 434 projecting forward, $\Omega$-shaped; antenna much longer than proboscis. However, given the overall 435 similarity of the three species in proportions of body regions, appendages, and wing venation, 436 these differences do not warrant erecting a separate genus. The finding adds another record to the 437 pattern of apparently shared fossil taxa between Cambay and Baltic amber, as already been 438 reported from the Diptera (Grimaldi \& Singh, 2012; Stebner et al., 2017), bees (Engel et al., 439 2013), and termites (Engel et al., 2011).

440 The most unexpected finding is Lygistorrhina in Cambay amber. This is a clearly defined, 441 unquestionably monophyletic genus. The only difference between the 21 Recent species and the 442 Cambay species is that the latter lacks the shallow depression on the lateral surface of the 443 metacoxa, and the setae on the laterotergite are not in a row on the posterior margin. Otherwise, 444 L. indica $\mathrm{n}$. sp. is clearly closely related to recent Lygistorrhina.. This approximately triples the 445 age of Lygistorrhina, the prior oldest record being a species in Miocene Dominican amber 446 (Grund, 2012; there are at least four other species of Lygistorrhina in this amber [D. Grimaldi, 447 unpubl.]). Biogeographically, this finding is difficult to interpret because of the poor geographical 448 sampling of the Recent species of Lygistorrhina. For example, there are nine New World species 449 (but with nearly 30 total, based on study of museum specimens by D.G.); five species in central 450 Africa and the Comoro Islands; three in southeast Asia; and three species in the Australasian 451 region (including New Caledonia and the Fiji archipelago). There are few or no described 452 species from large areas: most of Central America, all of the Greater Antilles, Andean South 453 America, Madagascar, India, southern China, much of southeast Asia, most of Indonesia, and all 454 of New Guinea. Based on study of extant material by the senior author (D. G.) there are likely to 455 be well over 100 living species in existence. Unfortunately, living species are morphologically 456 challenging to separate, and so morphology will probably yield an insufficient number of 457 characters for an eventual phylogenetic study of the genus. 


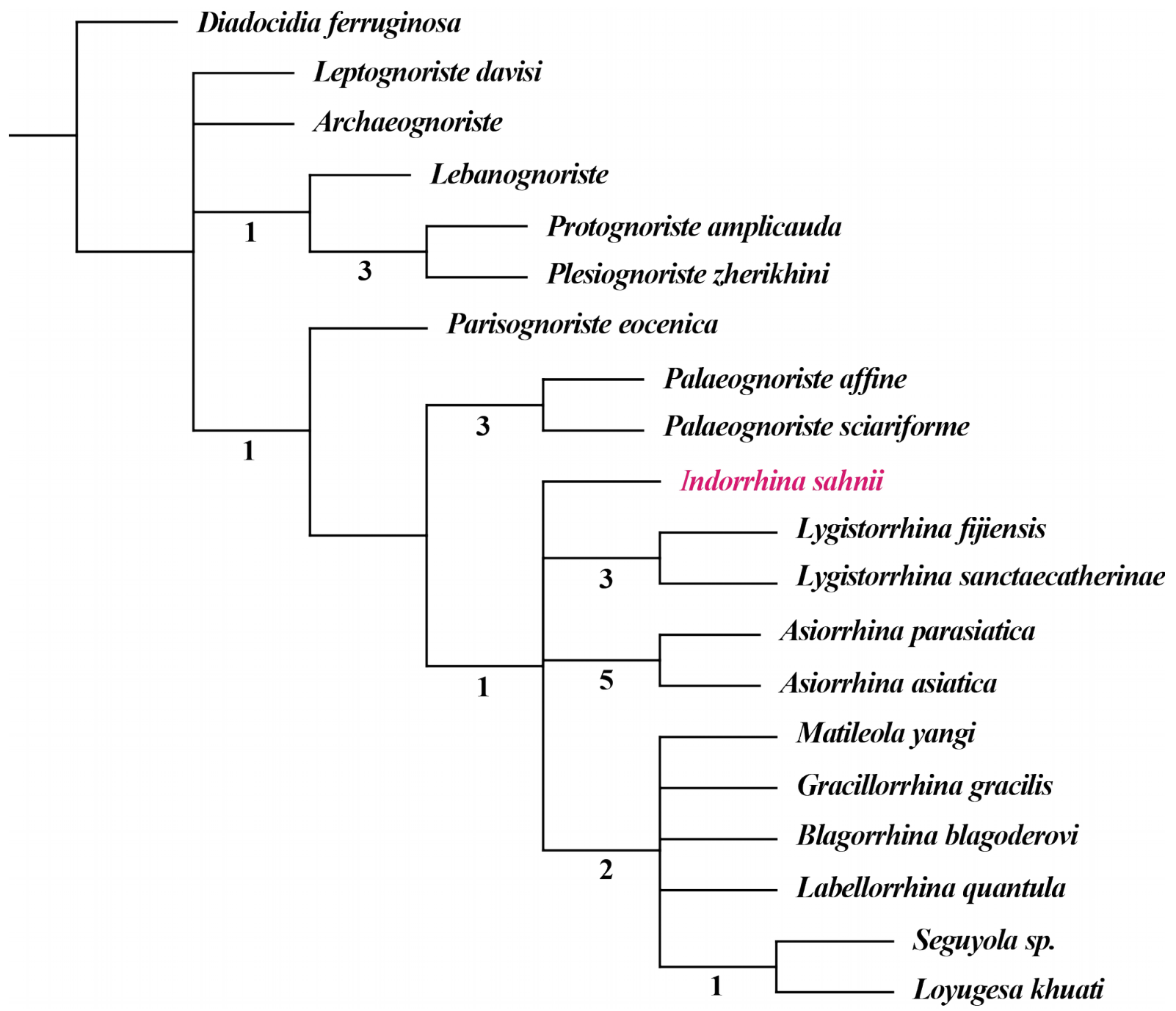

458 Fig. 11. Phylogeny of Lygistorrhinidae. Strict consensus cladogram of 9 MPT (181 steps), based 459 on the matrix of Blagoderov et al., 2010 and including Indorrhina sahnii from Cambay amber. 460 Numbers below branches refer to Bremer support values. 


\section{CONCLUSIONS}

462 Considering the scarcity of Eocene amber deposits, Cambay amber is of great significance

463 because it fills a gap in the spatial fossil record of the Paleogene and provides information about

464 phylogenetic relationships, divergence estimations, and biogeographic patterns of certain groups,

465 and adds information about the palaeoenvironment.

466 The discovery of a diverse assemblage of Lygistorrhinidae in Cambay amber reinforces the

467 reconstruction of a tropical palaeoenvironment and, at the same time, indicates climatic

468 differences between the Cambay amber forest (tropical) and the Baltic amber forest, which was

469 located distinctly further north and presumably after the peak of Eocene global warming.

470 The finding of Palaeognoriste in Cambay amber adds further evidence that faunal exchange

471 between India and Europe/Asia occurred before the formation of Cambay amber in the early

472 Eocene. In this regard the discovery of Lygistorrhinidae in Eocene Fushun amber from northeast

473 China, Paleocene amber from Sakhalin Island, Russia, Rovno amber from the Ukraine, and any

474 additional species in the Eocene amber from Oise, France would be very interesting for further

475 studies.

476 The oldest finding of Lygistorrhina clearly has major implications for estimates of divergence

477 times in the family as it indicates that this group was in existence since at least the early Eocene,

478 which may explain its worldwide distribution, including some remote islands. 


\section{ACKNOWLEDGEMENTS}

480 The authors thank Ashok Sahni (Centre of Advanced Study in Geology, Panjab University,

481 Chandigarh, India) and Rajendra. S. Rana (Department of Geology, Hemwati Nandan Bahuguna

482 Garhwal University, Srinagar, India) for support in field work. The authors are grateful to the

483 authorities of the Tadkeshwar lignite mine for assistance during fieldwork in Gujarat, India. H.S.

484 thanks the director of the Birbal Sahni Institute of Palaeosciences (Lucknow, India) for his

485 support. F. S. thanks Simon Gunkel (Steinmann Institut, University of Bonn, Germany) for

486 professional support. 


\section{REFERENCES}

488 Blagoderov V, Grimaldi D. 2004. Fossil Sciaroidea (Diptera) in Cretaceous Ambers, exclusive of 489 Cecidomyiidae, Sciaridae, and Keroplatidae. American Museum Novitates 3433:1-76.

490 Blagoderov V, Hippa H, Nel A. 2010. Parisognoriste, a new genus of Lygistorrhinidae (Diptera:

491 Sciaroidea) from Oise amber with redescription of Palaeognoriste Meunier.

492 ZooKeys 50:79-90.

Blagoderov V, Hippa H, Ševčík J. 2009. Asiorrhina, a new Oriental genus of Lygistorrhinidae (Diptera: Sciaroidea) and its phylogenetic position. Zootaxa 2295:31-45.

Blagoderov V, Papp L, Hippa H. 2013. A new species of Lygistorrhina Skuse (Diptera: 10.3897/BDJ.1.e962.

Borkent A. 2000. Biting midges (Ceratopogonidae: Diptera) from Lower Cretaceous Lebanese amber with a discussion of the diversity and patterns found in other ambers. In: Grimaldi D, ed. Studies on fossils in amber, with particular reference to the Cretaceous of New Jersey. Leiden: Backhuys Publishers, 355-451.

Brasero N, Nel A, Michez D. 2009. Insects from the early Eocene amber of Oise (France): diversity and palaeontological significance. Denisia 26, zugleich Kataloge der oberösterreichischen Landesmuseen Neue Serie 86:41-52.

505 Clementz M, Bajpai S, Ravikant V, Thewissen JGM, Saravanan N, Singh IB, Prasad V. 2011. 506 Early Eocene warming events and the timing of terrestrial faunal exchange between India and 507 Asia. Geology 39:15-18.

508 Edwards FW. 1912. Lygistorrhina urichi, a new Mycetophilid from Trinidad. Annals of Natural 509 History 10:203-204. 
510 Edwards FW. 1925. British Fungus Gnats (Diptera, Mycetophilidae). With a revised generic

511 classification of the family. Transactions of the Entomological Society of London 72:505-670.

512 Edwards FW. 1926. XIV. Diptera Nematocera from the mountains of Borneo. Sarawak Museum

513 Journal 3:243-278.

514 Edwards FW. 1932. New Brazilian Mycetophilidae (Diptera). Revista de Entomologia 2:138-149.

515 Engel MS, Grimaldi DA, Nascimbene PC, Singh H. 2011. The termites of Early Eocene Cambay

516 amber, with the earliest record of Termitidae (Isoptera). ZooKeys 148:105-123.

517 Engel MS, Ortega-Blanco J, Nascimbene PC, Singh H. 2013. The bees of Early Eocene Cambay

518 amber (Hymenoptera: Apidae). Journal of Melittology 25:1-12.

519 Evenhuis N. 2008. A new species of Lygistorrhina Skuse from Fiji (Diptera: Lygistorrhinidae).

520 Bishop Museum Occasional Papers 97:13-20.

521 Fungus Gnats Online. 2016. Available at http://sciaroidea.info/(accessed 4 November 2016).

522 Garg R, Ateequzzaman K, Prasad V, Tripathi SKM, Singh IB, Jauhri AK, Bajpai S. 2008. Age-

523 diagnostic dinoflagellate cysts from the lignite bearing sediments of the Vastan lignite mine,

524 Surat District, Gujarat, western India. Journal of the Palaeontological Society of India 53:99-105.

525 Goloboff PA, Farris JS, Nixon KC. 2008. TNT, a free program for phylogenetic analysis.

526 Cladistics 24:1-13.

527 Grimaldi D, Blagoderov V. 2001. A new genus of Lygistorrhinidae from Vietnam (Diptera:

528 Sciaroidea), and phylogenetic relationships in the family. Studia Dipterologica 8:43-57.

529 Grimaldi DA, Singh H. 2012. The extinct genus Pareuthychaeta in Eocene ambers (Diptera:

530 Schizophora: Ephydroidea). The Canadian Entomologist 144:17-28. 
531 Grund M. 2012. A long-beaked fungus gnat in Dominican amber. Annales Zoologici 62:639-642.

532 Hennig W. 1954. Flügelgeäder und System der Dipteren unter Berücksichtigung der aus dem 533 Mesozoikum beschriebenen Fossilien. Beiträge zur Entomologie 4:245-388.

534 Hennig W. 1966. The Diptera fauna of New Zealand as a problem in systematics and 535 zoogeography, [translated by P. Wygodzinsky]. Pacific Insects Monographs 9:1-81.

536 Hippa H, Mattsson I, Vilkamaa P. 2005. New taxa of the Lygistorrhinidae (Diptera: Sciaroidea) 537 and their implications for a phylogenetic analysis of the family. Zootaxa 960:1-34.

538 Hoffeins C, Hoffeins HW. 1996. Palaeognoriste sp. Ungewöhnliche Pilzmücke im Baltischen 539 Bernstein. [Palaeognoriste sp., an unusual fungus gnat in Baltic amber.]. Fossilien 13:311-314.

$540 \mathrm{Hu}$ X, Garzanti E, Moore T, Raffi I. 2015. Direct stratigraphic dating of India-Asia collision onset 541 at the Selandian (middle Paleocene, $59 \pm 1 \mathrm{Ma}$ ). Geology 43:859-862.

542 Huerta H, Ibañez-Bernal S. 2008. The family Lygistorrhinidae (Diptera: Sciaroidea) in Mexico 543 and the description of two new species. Zootaxa 1808:44-52.

544 Iturralde-Vinent MA. 2001. Geology of the Amber-bearing deposits of the Greater Antilles. 545 Caribbean Journal of Science 37:141-167.

546 Johannsen O A. 1909. Diptera. Fam. Mycetophilidae. Genera Insectorum, Fascicle 93:1-141.

547 Kent DV, Muttoni G. 2008. Equatorial convergence of India and early Cenozoic climate trends. 548 Proceedings of the National Academy of Science 105:16065-16070.

549 Lane J. 1946. New Brazilian Mycetophilidae (Diptera, Nematocera). Revista de Entomologia $550 \quad 17: 339-360$.

551 Lane J. 1958. On Amazonian Mycetophilidae (Diptera, Nematocera). Studia Entomologica $552 \quad 1: 209-216$. 
553 Maddison WP, Maddison DR. 2017. Mesquite: a modular system for evolutionary analysis.

554 Version $3.2 \mathrm{http}: / /$ mesquiteproject.org

555 Maksoud S, Azar D, Granier B, Gèze R. 2016. New data on the age of the Lower Cretaceous

556 amber outcrops of Lebanon. Palaeoworld. http://dx.doi.org/10.1016/j.palwor.2016.03.003

557 Matile L. 1979 (1978). Diptères Mycetophilidae de l'Archipel des Comores. Mémoires du 558 Muséum National d'Histoire Naturelle, Paris (A) (ZooI) 109:247-306.

559 Matile L. 1986. Dipteres Mycetophiloidea de Nouvelle-Caledonie. 1. Lygistorrhinidae. Annales 560 de la Société Entomologique de France 22:286-288.

561 Matile L. 1990a. Les Lygistorrhinidae de la region afrotropicale (Diptera: Mycetophiloidea). 562 Annales de la Société Entomologique de France 26:359-370.

563 Matile L. 1990b. Recherches sur la systématique et l'évolution des Keroplatidae (Diptera, 564 Mycetophiloidea). Mémoires du Muséum National d'Histoire Naturelle, Paris (A) (ZooI) 148:1565682.

566 Matile L. 1996. Une nouvelle espece afrotropicale du genre Lygistorrhina Skuse (Diptera, 567 Mycetophiloidea, Lygistorrhinidae). Revue Francaise d'Entomologie 18:30.

568 McAlpine JF. 1981. Morphology and Terminology - Adults. In: McAlpine JF, Peterson BV, 569 Shewell GE, Teskey HJ, Vockeroth JR, Wood DM, eds. Manual of Nearctic Diptera.

570 Canada: Research Branch, Agriculture Canada, 9-63.

571 Meunier F. 1904. Monographie des Cecidomyidae, des Sciaridae, des Mycetophilidae et des 572 Chironomidae de l'ambre de la Baltique. Annales de la Société scientifique de Bruxelles 28:12573275. 
574 Meunier F. 1912. Un nouveau Mycetophilidae de l'ambre de la Baltique $<$ Dipt.>. Bulletin de la

575 Société entomologique de France 3:88-90.

576 Okada I. 1937. Beitrag zur Kenntnis der Fungivoriden-Fauna Japans (Diptera) V:

577 Lygistorrhininae. Insecta Matsumurana 12:45-48

578 Pape T, Blagoderov V, Mostovski MB. 2011. Order Diptera Linnaeus, 1758. In: Z.-Q. Zhang, ed.

579 Animal biodiversity: An outline of higher-level classification and survey of taxonomic richness.

580 Zootaxa 3148: 222-229.

581 Papp L. 2002. Lygistorrhinidae (Diptera) from Taiwan. Annales Historico-Naturales Musei

582 Nationalis Hungarici 94:135-140.

583 Papp L. 2005. New species of Lygistorrhinidae (Diptera) from the Oriental region. Annales 584 Historico-Naturales Musei Nationalis Hungarici 97:151-161.

585 Punekar J, Saraswati PK. 2010. Age of the Vastan lignite in context of some oldest Cenozoic 586 fossil mammals from India. Journal of the Geological Society of India 76:49-72.

587 Rasnitsyn AP, Bashkuev AS, Kopylov DS, Lukashevich ED, Ponomarenko AG, Popov YA, 588 Rasnitsyn DA, Ryzhkova OV, Sidorchuk EA, Sukatsheva ID, Vorontsov DD. 2016. Sequence and 589 scale of changes in the terrestrial biota during the Cretaceous (based on materials from fossil 590 resins). Cretaceous Research 61:234-255.

591 Rust J, Singh H, Rana RS, McCann T, Singh L, Anderson K, Sarkar N, Nascimbene PC, Stebner 592 F, Thomas JC, Solórzano Kraemer M, Williams CJ, Engel MS, Sahni A, Grimaldi D. 2010.

593 Biogeographic and evolutionary implications of a diverse palaeobiota in amber from the early 594 Eocene of India. Proceedings of the National Academy of Sciences 107:18360-18365.

595 Sahni A, Saraswati PK, Rana RS, Kumar K, Singh, H, Alimohammadian H, Sahni N, Rose KD, 596 Singh L, Smith T. 2006. Temporal constraints and depositional palaeoenvironments of the Vastan 
597 lignite sequence, Gujarat: Analogy for the Cambay Shale hydrocarbon source rock. Indian 598 Journal of Petroleum Geology 15: 1-20.

599 Senior-White RA. 1922. New Ceylon Diptera (PartII.). Spolia Zeylanica 12:195-206.

600 Ševčík J, Kaspřák D, Mantič M, Fitzgerald S, Ševčíková T, Tóthová A, Jaschhof M. 2016.

601 Molecular phylogeny of the megadiverse insect infraorder Bibionomorpha sensu lato (Diptera)

602 PeerJ 4:e2563. DOI 10.7717/peerj.2563.

603

604 Shaw FR, Shaw MM. 1951. Relationships of certain genera of fungus gnats of the family

605 Mycetophilidae. Smithsonian Miscellaneous Collections 117:3-23.

606 Shi G, Grimaldi DA, Harlow GE, Wang J, Wang J, Yang M, Lei W, Li Q, Li X. 2012. Age

607 constraint on Burmese amber based on U-Pb dating of zircons. Cretaceous Research 37:155-163.

608 Singh H, Prasad M, Kumar K, Singh SK. 2015. Early Eocene macroflora and associated

609 palynofossils from the Cambay Shale Formation, western India: Phytogeographic and

610 palaeoclimatic implications. Palaeoworld 24:293-323.

611 Skuse FAA. 1890. Diptera of Australia. Nematocera. - Supplement II. Proceedings of the

612 Linnean Society of New South Wales 2:595-640.

613 Smith T, Kumar K, Rana RS, Folie A, Solé F, Noiret C, Steeman T, Sahni A, Rose K. 2016. New

614 early Eocene vertebrate assablage from western India reveals a mixed fauna of European and

615 Gondwana affinities. Geoscience Frontiers 7:969-1001.

616 Standke G. 2008. Bitterfelder Bernstein gleich Baltischer Bernstein? Eine geologische Raum-

617 Zeit-Betrachtung und genetische Schlussfolgerungen. Exkursionsführer und Veröffentlichungen

618 der Deutschen Gesellschaft für Geowissenschaften 236:11-33.

619 Stebner F, Szadziewski R, Singh H, Gunkel S, Rust J. (2017). Biting midges (Diptera:

620 Ceratopogonidae) from Cambay amber indicate that the Eocene fauna of the Indian subcontinent

621 was not isolated. PlosOne 12:e0169144. 
622 Thompson FC. 1975. Notes on the genus Lygistorrhina Skuse with the description of the first

623 Nearctic species (Diptera: Mycetophiloidea). Proceedings of the Entomological Society of

624 Washington 77:434-445.

625 Tonnoir AL. 1929. Australian Mycetophilidae. Synopsis of the genera. Proceedings of the 626 Linnean Society of New South Wales 54:584-614.

627 Tripathi SKM, Srivastava D. 2012. Palynology and palynofacies of the early Palaeogene lignite 628 bearing succession of Vastan, Cambay Basin, Western India. Acta Palaeobotanica 52:157-175.

629 Tuomikoski R. 1966. Systematic Position of Lygistorrhina Skuse (Diptera, Mycetophiloidea).

630 Annales Entomologici Fennici 32:254-260.

631 Wang B, Rust J, Engel MS, Szwedo J, Dutta S, Nel A, Fan Y, Meng F, Shi G,

632 Jarzembowski EA, Wappler T, Stebner F, Fang Y, Mao L, Zheng D, Zhang H.

633 2014. A Diverse Paleobiota in Early Eocene Fushun Amber from China. Current Biology $63424: 1606-1610$.

635 Williston SW. 1896. On the Diptera of St. Vincent (West Indies). Transactions of the Royal 636 Entomological Society of London 44:253-446. 